\title{
Effects of prepartum diets supplemented with rolled oilseeds on calf birth weight, postpartum health, feed intake, milk yield, and reproductive performance of dairy cows
}

\author{
R. Salehi, ${ }^{*}$ M. G. Colazo, $†$ M. Oba, ${ }^{*}$ and D. J. Ambrose ${ }^{*} \dagger^{1}$ \\ *Department of Agricultural, Food and Nutritional Science, University of Alberta, Edmonton, AB, T6G 2P5, Canada \\ †Livestock Research Branch, Alberta Agriculture and Forestry, Suite 307, 7000 - 113 Street NW, Edmonton, AB, T6H 5T6, Canada
}

\begin{abstract}
The objectives were to determine the effects of supplemental fat (no oilseed vs. oilseed) during late gestation and the source of fat (canola vs. sunflower seed), on dry matter intake (DMI), plasma metabolite concentrations, milk production and composition, calf birth weight, postpartum health disorders, ovarian function and reproductive performance in dairy cows. Pregnant Holstein cows, blocked by body condition and parity, were assigned to 1 of 3 diets containing rolled canola seed (high in oleic acid; $\mathrm{n}=43$ ) or sunflower (high in linoleic acid; $\mathrm{n}=45$ ) at $8 \%$ of dry matter, or no oilseed (control; $\mathrm{n}=43$ ), for the last $35 \pm 2 \mathrm{~d}$ of pregnancy. After calving, all cows received a common lactation diet. Blood samples were collected at wk -3 (i.e., 2 wk after initiation of prepartum diets) and at wk $+1,+2,+3$, +4 and +5 postpartum to determine the concentration of fatty acids $(\mathrm{mEq} / \mathrm{dL}), \beta$-hydroxybutyrate $(\mathrm{mg} / \mathrm{dL})$, and glucose $(\mathrm{mg} / \mathrm{dL})$. Ovarian ultrasonography was performed twice weekly to determine the first appearance of dominant $(10 \mathrm{~mm})$ and preovulatory-size $(\geq 16$ $\mathrm{mm}$ ) follicles, and ovulation. Uterine inflammatory status based on the proportion of polymorphonuclear leukocytes (PMN; subclinical endometritis: > $8 \%$ PMN) was assessed at d $25 \pm 1$ postpartum. Significant parity by treatment interactions were observed for DMI and milk yield. Prepartum oilseed supplementation, more specifically sunflower seed supplementation, increased postpartum DMI in primiparous cows without affecting prepartum DMI or milk yield. Contrarily, in multiparous cows, prepartum oilseed supplementation decreased both prepartum and postpartum DMI and milk yield during the first 2 wk. Regardless of parity, prepartum feeding of canola reduced postpartum DMI compared with those fed sunflower. Mean fatty acids
\end{abstract}

Received July 30, 2015.

Accepted January 20, 2016.

${ }^{1}$ Corresponding author: divakar.ambrose@gov.ab.ca concentrations at wk -3 were greater in cows given supplemental oilseed than those fed no oilseeds. Gestation length and calf birth weight were increased in cows given supplemental oilseed prepartum compared with cows fed no oilseeds, and a disproportionate increase in the birth weight of female calves was evident in cows fed oilseed. Total reproductive disorders tended to be greater in cows fed supplemental oilseed than those fed no oilseed (42 vs. 23\%). Furthermore, cows fed sunflower seed had greater incidences of dystocia (35 vs. 18\%) and total health disorders (52 vs. $32 \%$ ) than those fed canola seed. Added oilseed and type of oilseed did not affect uterine inflammation at $25 \pm 1$ d postpartum. Oilseed supplementation did not alter the intervals from calving to establishment of the first dominant follicle, preovulatory-size follicle, and ovulation, nor did it affect fertility (conception rate to first artificial insemination and proportion of pregnant cows by $150 \mathrm{~d}$ after calving). In summary, prepartum oilseed supplementation (6.2 to $7.4 \%$ ether extract, \% of dietary dry matter) decreased DMI during the entire experimental period (pre- and postpartum), decreased milk yield during early lactation in multiparous cows, and increased calf birth weight with no significant improvement in ovarian function and reproductive performance.

Key words: prepartum diets, oilseeds, calf birth weight, reproductive performance

\section{INTRODUCTION}

Plasma fatty acids concentrations usually increase early postpartum due to mobilization of adipose tissue because high-producing cows often cannot consume enough energy to meet requirements for milk production and maintenance (Bell, 1995; Drackley, 1999). An elevated concentration of fatty acids in the periparturient period is the major factor contributing to postpartum accumulation of lipids in the liver (Bell, 
1981). Cow performance is negatively affected when lipid accumulation in the liver is excessive (Herdt, 1988). Therefore, management strategies that minimize adipose tissue mobilization postpartum may be beneficial to improve cow performance. Whereas postpartum fat supplementation is a common practice in the dairy industry (reviewed by Santos et al., 2008), prepartum fat supplementation is less common. Although plasma fatty acid concentrations increase when fat is supplemented to the diet of lactating dairy cows (Grummer and Carroll, 1991), this response is not unequivocal. Grum et al. (1996) reported that feeding fat (6.5\% of dietary DM; Qual-Fat mainly high in palmitic and oleic acids, National By-products Inc., Mason City, IL) to dairy cows during the dry period (from 60 to $7 \mathrm{~d}$ before expected calving date) essentially abolished accumulation of triacylglycerol in the liver during the postpartum period immediately after calving. Drackley (1999) has proposed that alterations in liver metabolism through fatty acid supplementation might adapt the ruminant liver to contend with the large peripartal increases in blood fatty acids and minimize the risk for the development of fatty liver. Importantly, the type of fatty acid supplements may affect plasma concentrations of fatty acids. Cows fed linseed oil (high in $\alpha$-linolenic acid; $1.35 \%$ of dietary DM prepartum and $1.5 \%$ of dietary DM postpartum) had greater plasma concentrations of fatty acids at 2 and $5 \mathrm{wk}$ postpartum and greater hepatic concentrations of fat at 2 wk postpartum compared with cows fed a high linoleic acid fat formulated at the same fatty acid concentrations (Amaral, 2008). These results collectively indicate that, in dairy cattle, the effect of prepartum fat supplementation on plasma metabolite concentration during calving transition period is not consistent.

In a previous study, Colazo et al. (2009) reported that dry cows fed diets supplemented with linola (high in linoleic acid) or flax seed (high in $\alpha$-linolenic acid) had a numerically lower incidence of ovarian cysts and ovulated sooner after calving compared with those cows fed diets supplemented with canola (high in oleic acid). Prepartum dietary treatments did not affect calf birth weight, postpartum health disorders, energy balance, or fertility (Colazo et al., 2009); however, a control diet without supplemental fat was not included in that study. As canola seed is a common ingredient in dairy cattle rations, we wanted to confirm our previous observations and further investigate the effect of dietary canola seed on reproductive function. We hypothesized that cows given a prepartum diet supplemented with canola seed will have a longer interval from calving to first ovulation, as observed previously, compared with those fed diets supplemented with no oilseed or with sunflower seed. Our objectives were to determine the effects of supplemental fat (no oilseed vs. oilseed) during late gestation and the source of fat (canola vs. sunflower seed), on DMI, plasma metabolite concentrations, milk production and composition, calf birth weight, postpartum health disorders, ovarian function, and reproductive performance in dairy cows.

\section{MATERIALS AND METHODS}

\section{Animals and Diets}

One hundred thirty-one dry pregnant Holstein cows, parity 1 to 5 (46 primiparous and 85 multiparous), were used in the study. Thirty-five days $(35 \pm 2 \mathrm{~d})$ before the expected calving date (wk -5 ), cows were blocked by BCS and parity, and assigned to 1 of 3 dietary treatments: sunflower seed (high in linoleic acid), canola seed (high in oleic acid), or no oilseed (control), with rolled oilseeds added at $8 \%$ on a DM basis. Oilseeds were rolled as described previously (Ambrose et al., 2006) before incorporation in the diet. Diets were offered ad libitum as a TMR containing barley silage, alfalfa hay, and concentrates. Upon calving, cows were placed on a common lactation diet. The ingredients and nutrient composition of both pre- and postpartum diets are presented in Table 1. The crude fat content and fatty acid profile of oilseeds are presented in Table 2 . The study was conducted at the Dairy Research Unit of the University of Alberta, with all animal experimental procedures approved by the University of Alberta's Animal Care and Use Committee for Livestock (Protocol \# AUP00000131), and animals were cared for according to the Canadian Council of Animal Care Guidelines (Olfert et al., 1993).

Cows were housed individually in tiestalls during preand postpartum periods, were fed once daily at 0800 $\mathrm{h}$, and had unrestricted access to water. Postpartum cows were allowed 1 to $2 \mathrm{~h}$ of exercise on weekdays, and milked twice daily in their stalls between 0400 and 0600 h (a.m.) and between 1530 and 1730 h (p.m.). Milk production was automatically recorded at each milking. Feed intake was recorded daily and weekly feed samples were taken from forages and concentrates to determine feed DM and diet composition (Sun and Oba, 2014). Ratios of feed ingredients (as-fed basis) for rations were adjusted weekly based on each feed's DM values. Body condition scoring was performed on all cows at wk -5 to block the cows for treatment assignment. Body condition score and BW were also recorded for a subset of cows $(\mathrm{n}=22$ cows per treatment including 12 cows per treatment used for milk and blood sampling) at wk 0 (calving time) and wk +5 . The same technician assigned BCS to each cow on a scale of 1 (emaciated) to 5 (overconditioned) (Edmonson et al., 1989). 
Table 1. Ingredients and nutrient composition (\% of DM unless otherwise noted) of pre- and postpartum diets

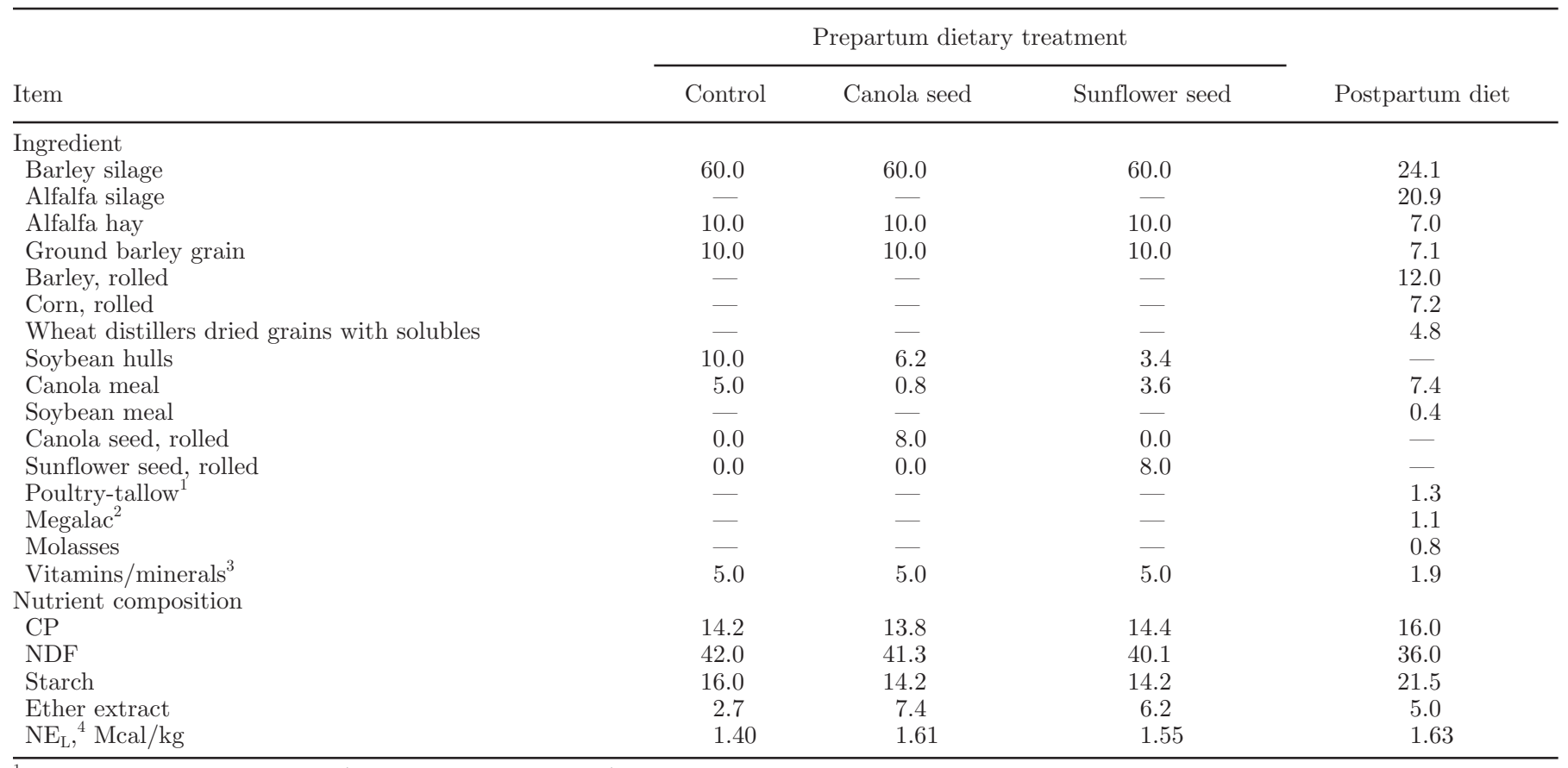

${ }^{1}$ Northern Alberta Processing (Edmonton, AB, Canada).

${ }^{2}$ Church and Dwight (Princeton, NJ).

${ }^{3}$ Contained $13.0 \% \mathrm{Ca}, 3.32 \% \mathrm{P}, 13.0 \% \mathrm{Na}, 5.59 \% \mathrm{Cl}, 5.20 \% \mathrm{Mg}, 0.47 \% \mathrm{~S}, 0.05 \% \mathrm{~K}, 3,295.2 \mathrm{mg} / \mathrm{kg}$ of Fe, $3,473.6 \mathrm{mg} / \mathrm{kg}$ of Cu, $6,305.8 \mathrm{mg} / \mathrm{kg}$ of $\mathrm{Mn}, 72.0 \mathrm{mg} / \mathrm{kg}$ of Co, $5,222.3 \mathrm{mg} / \mathrm{kg}$ of Zn, $34.03 \mathrm{mg} / \mathrm{kg}$ of Se, $158.6 \mathrm{mg} / \mathrm{kg}$ of I, $764.2 \mathrm{kIU} / \mathrm{kg}$ of vitamin A, $129.2 \mathrm{kIU} / \mathrm{kg}$ of vitamin D, and $2,906.5 \mathrm{kIU} / \mathrm{kg}$ of vitamin E (DSM, Nova Scotia, Canada).

${ }^{4} \mathrm{NE}_{\mathrm{L}}=0.0245 \times \mathrm{TDN}(\%)-0.12$.

Cow health status was monitored and recorded daily. Dystocia was defined as calving with assistance (easy pull), hard pull, or surgery (Sewalem et al., 2008). Retained fetal membrane was defined as the lack of detachment of fetal membranes within $24 \mathrm{~h}$ after calving (Roberts, 1986). Reproductive tracts of all cows were palpated per rectum at d $14 \pm 2$ postpartum for diagnosis of metritis. Presence of watery, fetid vaginal discharge of uterine origin with elevated rectal temperature $\left(>39.5^{\circ} \mathrm{C}\right)$ was diagnosed as puerperal metritis (Sheldon et al., 2006). An endometrial cytological sample was obtained on d $25 \pm 1$ postpartum from 95

Table 2. Crude fat content and fatty acid (FA) profile (g/100 g of total FA) of oilseeds added to prepartum experimental diets

\begin{tabular}{lcc}
\hline Item & Canola seed & Sunflower seed \\
\hline Crude fat, \% & 45.2 & 43.3 \\
FA profile of oilseeds & 4.0 & 6.8 \\
Palmitic acid (C16:0) & 1.8 & 5.2 \\
Stearic acid (C18:0) & 61.2 & 12.5 \\
Oleic acid (C18:1 cis-9) & 18.8 & 73.1 \\
Linoleic acid (C18:2n-6) & 9.6 & 0.7 \\
Q-Linolenic acid (C18:3n-3) & 0.6 & 0.3 \\
Arachidic acid (C20:0) & 4.0 & 1.4 \\
Other fatty acids & & \\
\hline
\end{tabular}

cows using a cytobrush (Medscand Medical, Malmö, Sweden) as described by Dourey et al. (2011), to evaluate uterine inflammatory status. The cows with $>8 \% \mathrm{PMN}$ in the cytological sample were defined as having subclinical endometritis and those with $\leq 8 \%$ PMN were defined as having a healthy uterus. Mastitis was defined as inflammation of the mammary gland with heat, pain, and induration detectable by manual palpation and confirmed by the California Mastitis Test (Schalm and Noorlander, 1957). Clinical ketosis was determined when animals had decreased appetite with evidence of elevated urine ketones $(>2.0 \mathrm{mmol} / \mathrm{L}$; Ketostix reagent strips, Bayer Inc., Mississauga, ON, Canada) after exclusion of other clinical disease.

\section{Milk and Blood Sample Collection}

Based on previous publications and a priori power analysis for sample size determination, we obtained milk and blood samples from a subset of 12 cows, selected randomly, per treatment. Samples for milk composition were obtained from 6 consecutive milking sessions (Tuesday p.m. to Friday a.m.) during wk +2 and +5 postpartum. 
Blood samples were collected 2 wk after initiation of prepartum diets $(\mathrm{wk}-3)$, first $(\mathrm{wk}+1)$, second ( $\mathrm{wk}$ $+2)$, third $(\mathrm{wk}+3)$, fourth (wk +4$)$, and fifth $(\mathrm{wk}+5)$ wk postpartum. Samples were collected at $8 \mathrm{~h}$ intervals over a 16-h period $(2200,0600$, and $1400 \mathrm{~h})$ in heparinized tubes (Vacutainer, Becton Dickinson and Co., Franklin Lakes, NJ), centrifuged $\left(3,000 \times g\right.$ at $4^{\circ} \mathrm{C}$ for $20 \mathrm{~min}$ ), and the plasma was harvested. Plasma samples collected at 2200 and $0600 \mathrm{~h}$ were kept at $4^{\circ} \mathrm{C}$ until the last sample collection at $1400 \mathrm{~h}$. A pooled sample was prepared by mixing equal quantities of plasma from the 3 consecutive collections and stored at $-20^{\circ} \mathrm{C}$ until analyzed for fatty acid profile (wk -3 and +1 ), fatty acids, BHB, and glucose.

\section{Reproductive Management}

The ovaries and uterus of 95 cows (sunflower: $\mathrm{n}=$ 33, canola: $\mathrm{n}=31$, and control: $\mathrm{n}=31$ ) were examined by transrectal ultrasonography (MicroMAXX, color Doppler scanner equipped with a multifrequency 5- to 10-MHz linear transducer, SonoSite Inc., Bothell, WA), twice weekly, from $7 \pm 1$ until $35 \pm 1 \mathrm{~d}$ after calving. We recorded the intervals from calving to first appearance of a 10-mm follicle (referred to as dominant follicle hereafter), and that of a 16-mm follicle (referred to as preovulatory-size follicle hereafter). Ovulation was confirmed by the absence of a dominant (diameter $\geq 10 \mathrm{~mm}$ ) follicle that had been detected at the previous examination, and subsequent corpus luteum (CL) formation (Colazo et al., 2009). Anovulatory follicles $\geq 25 \mathrm{~mm}$ in diameter that persisted for at least $10 \mathrm{~d}$ in the absence of a CL were defined as cysts (Garverick, 1997). Cows were subjected to a Presynch/Ovsynch protocol and timed AI (Moreira et al., 2001) at $75 \pm 3 \mathrm{~d}$ postpartum. Cows were inseminated by one technician with frozenthawed semen, and pregnancy diagnosis performed by ultrasonography $32 \mathrm{~d}$ after timed AI.

\section{Plasma Fatty Acid Profile and Metabolites}

Plasma fatty acids (NEFA-C kit, Wako Chemicals USA Inc., Richmond, VA), BHB (Roche Diagnostics, Indianapolis, IN), and glucose (P7119, Sigma-Aldrich, St. Louis, MO) were determined using commercially available kits in triplicate. The intra- and interassay coefficients of variation for fatty acids, BHB, and glucose were 1.49 and $3.32,2.51$ and 6.71 , and 1.38 and $2.42 \%$, respectively. Fatty acids in plasma samples were extracted as described by Folch et al. (1957). The fatty acid profile of extracted lipids was assessed by gas chromatography as previously described by CruzHernandez et al. (2007).

\section{Milk Composition}

Milk samples were analyzed for fat, protein, lactose, and MUN by infrared spectroscopy (AOAC International, 2002; method 972.16; MilkoScan 605, Foss North America, Brampton, ON, Canada) at the Alberta Central Milk Testing Laboratory (Edmonton, AB, Canada).

\section{Statistical Analyses}

The plasma concentrations of fatty acids, BHB, glucose, BCS, BW, plasma fatty acid profile, milk yield and composition, DMI, interval to dominant follicle, preovulatory-size follicle, ovulation, gestation length and calf birth weight were analyzed using the MIXED procedure of SAS (version 9.3, 2011; SAS Institute Inc., Cary, NC). The repeated-measures data (fatty acids, BHB, and glucose) were analyzed for each week separately. Preplanned contrast analysis was used to compare means for oilseed versus no oilseed and sunflower- versus canola-fed cows. The final statistical model included prepartum dietary treatment and parity as the main effects for metabolites, BCS, BW, gestation length, and intervals to dominant follicle, preovulatory-size follicle, and ovulation. The same approach was used for analyzing data of milk yield, milk composition, DMI, and calf birth weight with interaction of dietary treatment by parity or calf sex. Calf sex was used as covariate for interval to dominant follicle, preovulatory-size follicle, and ovulation. The interval from calving to first ovulation was also evaluated with survival analysis (PROC LIFETEST). Dietary treatment, time (d), and status (with the value 0 indicating censoring) were included in the model. Total reproductive disorders were defined as the sum of retained fetal membranes, metritis, vaginal discharge, and ovarian cyst incidence. Total health disorders were defined as the sum of retained fetal membranes, metritis, vaginal discharge, ovarian cyst, clinical ketosis, mastitis, and dystocia. The statistical model used to evaluate the effect of prepartum dietary treatment by uterine inflammatory status interaction [healthy $(\leq 8 \%$ $\mathrm{PMN})$ or subclinical endometritis ( $>8 \% \mathrm{PMN})]$ on reproductive performance included prepartum dietary treatment, uterine inflammatory status, and parity as the main effects, and prepartum dietary treatment by PMN category as interaction. The proportion of cows that ovulated within $35 \mathrm{~d}$ after calving (yes or no), conceived (yes or no) at the first TAI and by 150 or 250 DIM, or had any type of disorders (dystocia, retained fetal membranes, metritis, vaginal discharge, subclinical endometritis, ovarian cyst, mastitis, clinical ketosis, total reproductive disorders, or total health disorders) 
or death were analyzed using the PROC GENMOD procedure of SAS. Model specifications included a binomial distribution and logit link function and calf sex as covariate.

The Pearson test was used to calculate the associations of pre- and postpartum DMI and PMN percentage at $25 \pm 1$ DIM with intervals to formation a dominant follicle, preovulatory-size follicle, and first ovulation (n $=95$ cows in total). The association between prepartum DMI and calf birth weight was evaluated first in all cows $(n=131)$ regardless of parity and diet, and then within prepartum dietary treatments (control, $\mathrm{n}=43$; canola, $\mathrm{n}=43$; sunflower, $\mathrm{n}=45$ ), and finally within parity groups: primiparous $(\mathrm{n}=46)$ or multiparous ( $\mathrm{n}$ $=85$ ) cows. All data are reported as mean \pm standard errors with $P<0.05$ considered significant, and $P>$ 0.05 but $<0.10$ considered trends.

\section{RESULTS}

\section{BCS, BW, and Feed Intake}

Prepartum dietary supplementation of oilseed and type of oilseed did not affect BCS and BW at wk -5 (BW: $623.6 \pm 18.4 \mathrm{~kg}$, BCS: $3.33 \pm 0.04$ ), wk 0 (BW: $610.6 \pm 22.9 \mathrm{~kg}$, BCS: $3.49 \pm 0.04$ ), or wk +5 (BW: $556.3 \pm 15.2 \mathrm{~kg}$, BCS: $3.06 \pm 0.05)$. Significant parity by treatment interactions were observed for DMI $(P<$ $0.05)$, and results are shown separately for primiparous and multiparous cows (Figure 1). Oilseed supplementation during the last $5 \mathrm{wk}$ of gestation did not affect prepartum DMI in primiparous cows compared with no oilseed, but increased postpartum DMI from wk +2 to +5 (Figure 1A). More specifically, primiparous cows fed sunflower seed prepartum had the greatest postpartum DMI. In contrast, prepartum oilseed supplementation decreased both pre- and postpartum DMI in multiparous cows, and postpartum DMI reduction was greater in cows fed canola seed before calving (Figure 1B).

\section{Plasma Fatty Acid Profile and Metabolites}

In wk $-3, \mathrm{C} 18: 1$ and $\mathrm{C} 18: 2$ were highest in cows fed diets supplemented with canola and sunflower seed, respectively. In wk +1 , plasma C18:2 remained greater in cows fed sunflower seed prepartum compared with canola fed cows. Plasma concentrations of $\mathrm{C} 18: 3$ were also significantly increased in canola fed cows both during wk -3 and +1 (Table 3 ).

The plasma concentration of fatty acids was greater $(P=0.004)$ at wk -3 in cows given supplemental oilseeds compared with those given no oilseed (Table 4); additionally, cows fed canola had greater fatty acids concentration than those fed sunflower at wk +4 .
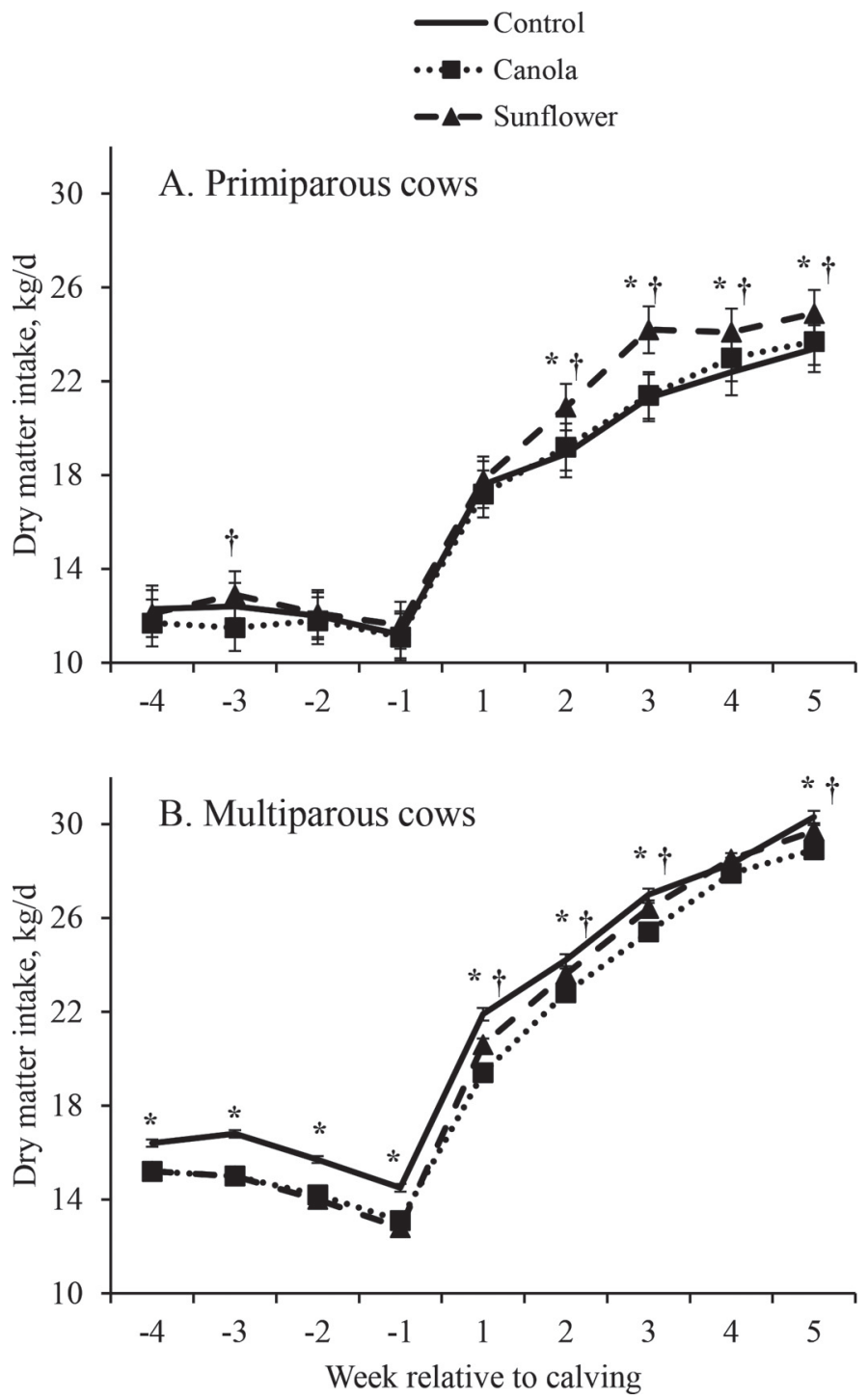

Figure 1. Effects of prepartum dietary treatment on DMI during calving transition for (A) primiparous cows, and (B) multiparous cows. *Significant effect of prepartum oilseed supplementation $(P<0.05)$; $\dagger$ significant effects of type of oilseed supplementation $(P<0.05)$. The mean $( \pm$ SEM $)$ prepartum DMI in primiparous cows were $11.9 \pm 0.1$, $11.5 \pm 0.1$, and $12.1 \pm 0.1$ and postpartum DMI were $20.9 \pm 0.1,20.7$ \pm 0.1 , and $22.3 \pm 0.1 \mathrm{~kg} / \mathrm{d}$, in control, canola, and sunflower groups, respectively. In multiparous cows, mean $( \pm$ SEM $)$ prepartum DMI were $15.8 \pm 0.1,14.3 \pm 0.1$, and $14.2 \pm 0.1$ and postpartum DMI were 26.3 $\pm 0.1,24.8 \pm 0.1$, and $25.7 \pm 0.1 \mathrm{~kg} / \mathrm{d}$, for control, canola, and sunflower, respectively.

Prepartum dietary treatments did not affect concentrations of plasma BHB and glucose during pre- and postpartum periods (Table 4 ).

\section{Milk Yield and Composition}

A significant parity by treatment interaction was observed for milk yield $(P<0.05)$; hence, results are 
Table 3. Effects of prepartum dietary treatment on fatty acid profile of plasma $(\mathrm{g} / 100 \mathrm{~g}$ of total fatty acids; mean \pm SEM) in dairy cows in wk -3 and +1 relative to calving

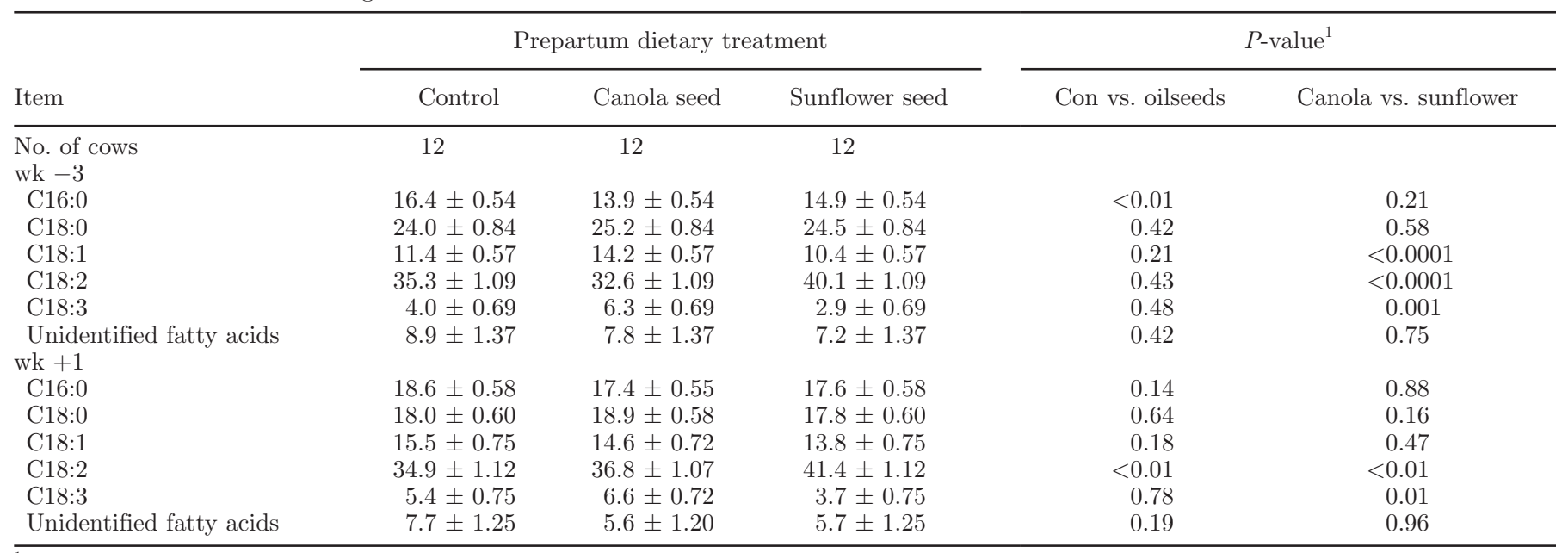

${ }^{1}$ Con vs. oilseed $=$ no oilseed (control) vs. oilseed supplementation; canola vs. sunflower $=$ type of oilseed supplementation.

shown separately for primiparous and multiparous cows (Figure 2). In primiparous cows, prepartum oilseed supplementation and type of supplemental oilseed did not affect milk yield compared with no oilseed. In multiparous cows, milk yield was lower in prepartum oilseed-fed cows during wk $+1,+2$, and +4 postpartum than those fed no oilseed. No differences were detected among treatments at $\mathrm{wk}+3$ and +5 .
Prepartum oilseed supplementation decreased milk protein yield $(\mathrm{kg} / \mathrm{d})$ in wk +2 and +5 ; a significant parity by treatment interaction was observed for milk protein production $(P<0.05)$ in wk +2 (Table 5$)$. Although prepartum oilseed supplementation did not affect milk protein yield in primiparous cows, it reduced milk protein yield in multiparous cows in wk +2 by $0.19 \mathrm{~kg} / \mathrm{d}$. Prepartum oilseed supplementation also

Table 4. Effect of prepartum dietary treatments on plasma metabolites (mean $\pm \mathrm{SEM}$ )

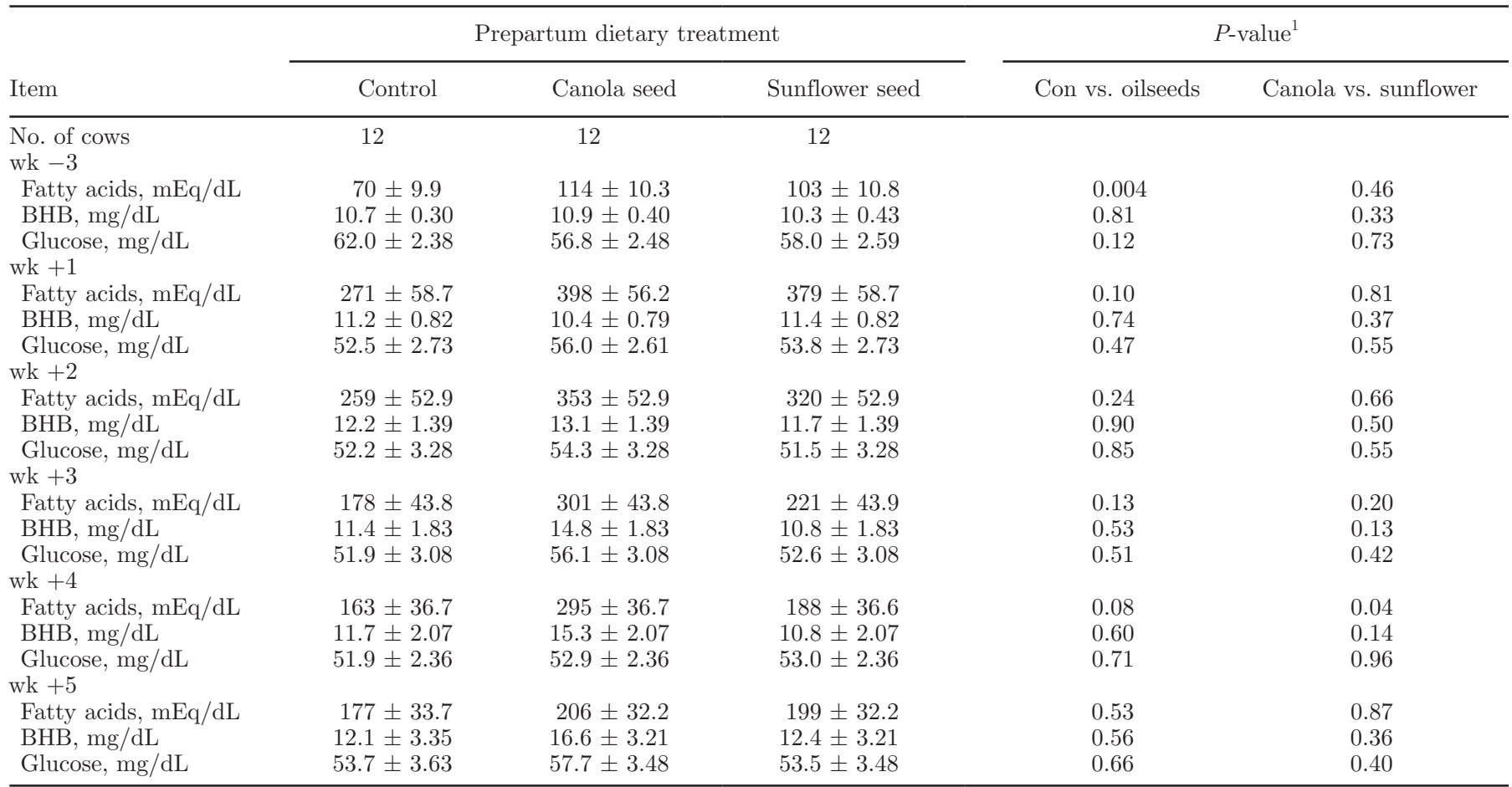

${ }^{1}$ Con vs. oilseed $=$ no oilseed $($ control) vs. oilseed supplementation; canola vs. sunflower $=$ type of oilseed supplementation. 
reduced MUN (mg/dL) in wk +2 and tended to reduce milk fat production $(\mathrm{kg} / \mathrm{d})$ in $\mathrm{wk}+5$. Additionally, prepartum oilseed supplementation increased lactose $(\%)$ in wk +5 . Type of supplemental oilseed (canola vs. sunflower) did not influence milk composition during wk +2 and +5 .

\section{Gestation Length and Calf Birth Weight}

Prepartum oilseed supplementation increased gestation length (Table 6$)$, but diet by parity $(P=0.44)$ and diet by fetal sex $(P=0.32)$ interactions on gestation length were not significant. Cows that were fed supplemental oilseed prepartum delivered heavier calves than those fed no supplemental oilseed (Table 6). Moreover, calf birth weight was significantly influenced $(P=0.02)$ by the interaction between dietary treatment and calf sex, with female calf birth weight being greater in cows that received supplemental oilseed during the prepartum period. More specifically, mean birth weight of female calves tended to be greater in cows that received sunflower seed prepartum than in those that received canola. A diet by parity interaction did not influence $(P$ $=0.93)$ calf birth weight.

\section{Ovarian Function and Pregnancy}

Prepartum dietary treatments affected neither the intervals from calving to formation of a dominant follicle, preovulatory-size follicle, and first ovulation, nor the proportion of cows that ovulated by 35 DIM (Table 7). Furthermore, we detected no significant difference among dietary treatments in the interval from calving to first ovulation, based on survival analysis. Although prepartum oilseed supplementation and type of supplemental oilseeds did not influence pregnancy at first TAI or the proportion of pregnant cows by 150 DIM, the proportion of pregnant cows by 250 DIM tended to be greater in oilseed-supplemented groups (Table 7).

\section{Postpartum Health and Reproductive Disorders}

The effects of prepartum diets on the incidence of early postpartum reproductive and health disorders are summarized in Table 8. The overall incidence of retained fetal membranes, metritis, vaginal discharge, and ovarian cysts, collectively referred to as total reproductive disorders, tended to be greater in cows fed supplemental oilseed during the prepartum period, but there was no difference between canola and sunflower treatments. Cows fed sunflower seed had a significantly greater incidence of dystocia and total health disorders than those fed canola. Oilseed supplementation and type of oilseed added to the diet did not affect the proportion of cows with subclinical endometritis at 25 DIM (Table 8).

The interactions between diets and uterine health based on PMN category on the intervals to the establishment of the first dominant follicle, formation of a preovulatory-size follicle, and first ovulation are presented in Table 9. Postpartum reproductive performance was not influenced by uterine inflammatory status (healthy vs. subclinical endometritis) and prepartum dietary treatments.
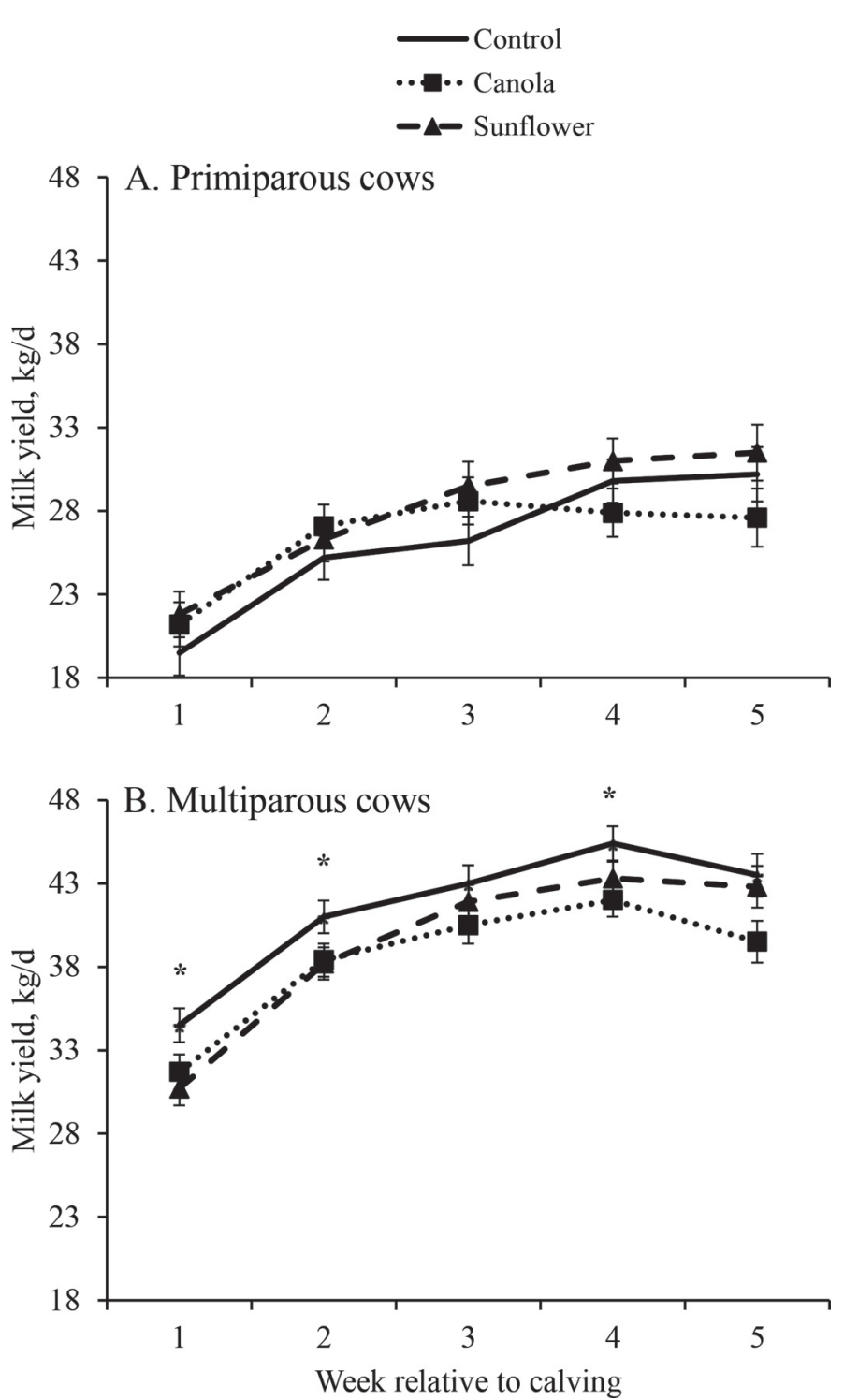

Figure 2. Effects of prepartum dietary treatment on mean $( \pm$ SEM) milk yield for (A) primiparous cows, and (B) multiparous cows across weeks. *Significant effect of prepartum oilseed supplementation $(P<$ $0.05)$. The mean milk yields $(\mathrm{kg} / \mathrm{d} ; \pm \mathrm{SEM})$ of primiparous cows were $25.2 \pm 0.6$ (control), $27.3 \pm 0.6$ (canola), and $28.0 \pm 0.6$ (sunflower) and that of multiparous cows were $41.4 \pm 0.4$ (control), $38.4 \pm 0.4$ (canola), and $39.3 \pm 0.4$ (sunflower). 
Table 5. Effect of prepartum dietary treatment on milk composition (mean \pm SEM)

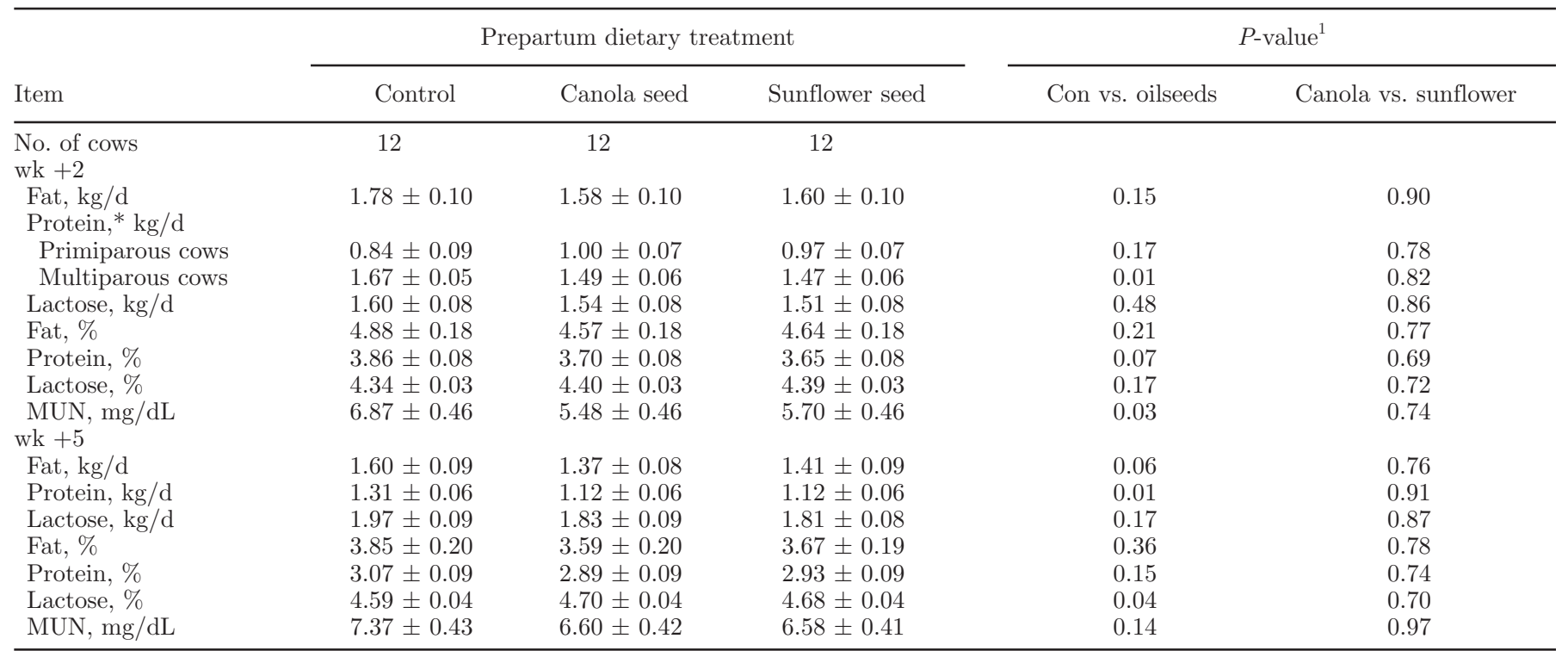

${ }^{1}$ Con vs. oilseed $=$ no oilseed $($ control) vs. oilseed supplementation; canola vs. sunflower $=$ type of oilseed supplementation.

*Significant treatment by parity interaction $(P<0.05)$.

\section{Associations Among DMI, PMN, Ovarian Function, and Calf Birth Weight}

The interval from calving to formation of first dominant follicle was positively correlated with PMN percentage $(\mathrm{r}=0.30, P=0.003)$. The interval from calving to the establishment of a preovulatory-size follicle was also correlated with PMN percentage $(\mathrm{r}=0.38, P=$ 0.002 ) and negatively correlated with mean postpartum DMI $(\mathrm{r}=-0.29, P=0.004)$. However, none of factors evaluated during the pre- and postpartum periods was associated with the interval to first ovulation. Moreover, the interval from calving to first ovulation had a positive association with that of dominant follicle $(\mathrm{r}$ $=0.23, P=0.04)$ and preovulatory-size follicle $(\mathrm{r}=$ $0.45, P<0.0001)$. Prepartum DMI was associated (r $=0.20 ; P=0.02$ ) with calf birth weight when all cows were considered, regardless of parity and dietary treatment. When analyzed by dietary treatment, prepartum
DMI influenced calf birth weight in control cows $(\mathrm{r}=$ $0.40 ; P=0.01)$ and canola-fed cows $(\mathrm{r}=0.33 ; P=$ $0.03)$ but not in cows fed sunflower seed $(\mathrm{r}=0.07 ; P=$ 0.62 ). When analyzed by parity, prepartum DMI and calf birth weight were not associated (primiparous: $\mathrm{r}=$ $-0.06 ; P=0.68$; multiparous: $\mathrm{r}=-0.18 ; P=0.11)$.

\section{DISCUSSION}

\section{Calf Birth Weight, Postpartum Health, and Reproductive Performance}

In previous work from our laboratory, Colazo et al. (2009) found that the type of oilseed supplemented during the prepartum period influenced the interval from calving to first ovulation postpartum. Cows fed diets supplemented with either linola or flax seed had a shorter interval from calving to first ovulation than those fed a diet supplemented with canola seed.

Table 6. Effect of prepartum dietary treatment on gestation length and calf birth weight (mean \pm SEM)

\begin{tabular}{|c|c|c|c|c|c|}
\hline \multirow[b]{2}{*}{ Item } & \multicolumn{3}{|c|}{ Prepartum dietary treatment } & \multicolumn{2}{|c|}{$P$-value ${ }^{1}$} \\
\hline & Control & Canola seed & Sunflower seed & Con vs. oilseeds & Canola vs. sunflower \\
\hline Gestation length, d & $273 \pm 0.9$ & $275 \pm 0.9$ & $277 \pm 0.9$ & 0.008 & 0.32 \\
\hline Calf birth weight, ${ }^{2} \mathrm{~kg}$ & $41.0 \pm 0.84$ & $42.9 \pm 0.83$ & $44.4 \pm 0.83$ & 0.01 & 0.15 \\
\hline Male & $43.7 \pm 1.27$ & $44.7 \pm 1.12$ & $45.1 \pm 1.09$ & 0.41 & 0.78 \\
\hline
\end{tabular}

${ }^{1}$ Con vs. oilseed $=$ no oilseed $($ control) vs. oilseed supplementation; canola vs. sunflower $=$ type of oilseed supplementation.

${ }^{2}$ Calf birth weight was not influenced $(P=0.93)$ by diet $\times$ parity interaction. 
Table 7. Effect of prepartum dietary treatments on interval from calving to formation of dominant follicle, preovulatory-size follicle, and first ovulation (mean $\pm \mathrm{SEM})$

\begin{tabular}{|c|c|c|c|c|c|}
\hline \multirow[b]{2}{*}{ Item $^{1}$} & \multicolumn{3}{|c|}{ Prepartum dietary treatment } & \multicolumn{2}{|c|}{$P$-value ${ }^{2}$} \\
\hline & Control & Canola seed & $\begin{array}{c}\text { Sunflower } \\
\text { seed }\end{array}$ & $\begin{array}{l}\text { Con vs. } \\
\text { oilseeds }\end{array}$ & $\begin{array}{l}\text { Canola vs. } \\
\text { sunflower }\end{array}$ \\
\hline No. of cows & 31 & 31 & 33 & - & - \\
\hline Interval to dominant follicle, $\mathrm{d}$ & $8.9 \pm 0.52$ & $9.2 \pm 0.47$ & $10.0 \pm 0.44$ & 0.25 & 0.27 \\
\hline Interval to preovulatory-size follicle, $\mathrm{d}$ & $13.5 \pm 0.87$ & $15.0 \pm 0.79$ & $15.3 \pm 0.75$ & 0.12 & 0.81 \\
\hline Interval to first ovulation, ${ }^{3} \mathrm{~d}$ & $20.7 \pm 1.59$ & $22.9 \pm 1.50$ & $20.6 \pm 1.41$ & 0.47 & 0.17 \\
\hline Proportion of pregnant cows by 150 DIM, no. (\%) & $13(41.9)$ & $16(51.6)$ & $14(42.4)$ & 0.78 & 0.27 \\
\hline Proportion of pregnant cows by 250 DIM, no. (\%) & $18(58.1)$ & $23(74.2)$ & $24(72.7)$ & 0.06 & 0.62 \\
\hline
\end{tabular}

${ }^{1}$ Dominant follicle $=$ follicle of $\geq 10 \mathrm{~mm}$ diameter; preovulatory-size follicle $=$ follicle of $\geq 16 \mathrm{~mm}$ diameter.

${ }^{2}$ Con vs. oilseed $=$ no oilseed $($ control) vs. oilseed supplementation; canola vs. sunflower $=$ type of oilseed supplementation.

${ }^{3}$ Ovaries were monitored by ultrasonography from d $7 \pm 1$ to $35 \pm 1$ postpartum.

However, prepartum dietary treatment did not affect the diameter of the largest follicle at $7 \mathrm{~d}$ postpartum (Colazo et al., 2009). In the present study, prepartum oilseed supplementation and type of oilseed did not affect the intervals from calving to formation a dominant follicle, to formation of a preovulatory-size follicle, to ovulation, or the proportion of cows that ovulated by $35 \mathrm{~d}$ postpartum. Due to the scarcity of reports on the effects of prepartum dietary fatty acids on interval from calving to first ovulation, we compared our results with some studies that fed dietary fatty acids during both the pre- and postpartum periods. Juchem et al. (2010) fed 1 of 2 diets consisting of calcium salt ( $2 \%$ of DM) of either palm oil (high in palmitic acid, $\mathrm{n}=246$ ) or trans-octadecenoic acid $(\mathrm{n}=255)$ from $25 \mathrm{~d}$ prepartum to $80 \mathrm{~d}$ of lactation. Ovaries were examined weekly by ultrasonography until the sixth week of lactation to determine the first postpartum ovulation based on the presence of a CL. In another study (Caldari-Torres et al., 2011), cows were fed diets containing fat supplements enriched in saturated fatty acids $(1.5 \%$ of DM, $\mathrm{n}=10$ ), calcium salts of trans-octadecenoic fatty acids (1.8\% of DM, $\mathrm{n}=10$ ) or calcium salts of safflower oil fatty acids (high in linoleic acid, $1.8 \%$ of $\mathrm{DM}, \mathrm{n}=9$ ). Diets were fed from 4 wk before until 7 wk after calving, and ovulation was determined by elevated ( $>1 \mathrm{ng} /$ $\mathrm{mL}$ ) plasma progesterone concentrations for 2 sampling days. In both studies, dietary treatments did not affect the interval from calving to first ovulation. The mean interval to first ovulation in the current study, regardless of dietary treatments, was shorter than what has been reported in previous studies: $31 \mathrm{~d}$ (Juchem et al., 2010), 33 d (Caldari-Torres et al., 2011), 32 d (Gümen et al., 2005), and $35 \mathrm{~d}$ (Ambrose and Colazo, 2007). Differences in the physiological status of animals and environmental influence associated with management

Table 8. Effect of prepartum dietary treatment on incidence (no., \% in parentheses) of early postpartum reproductive and health disorders

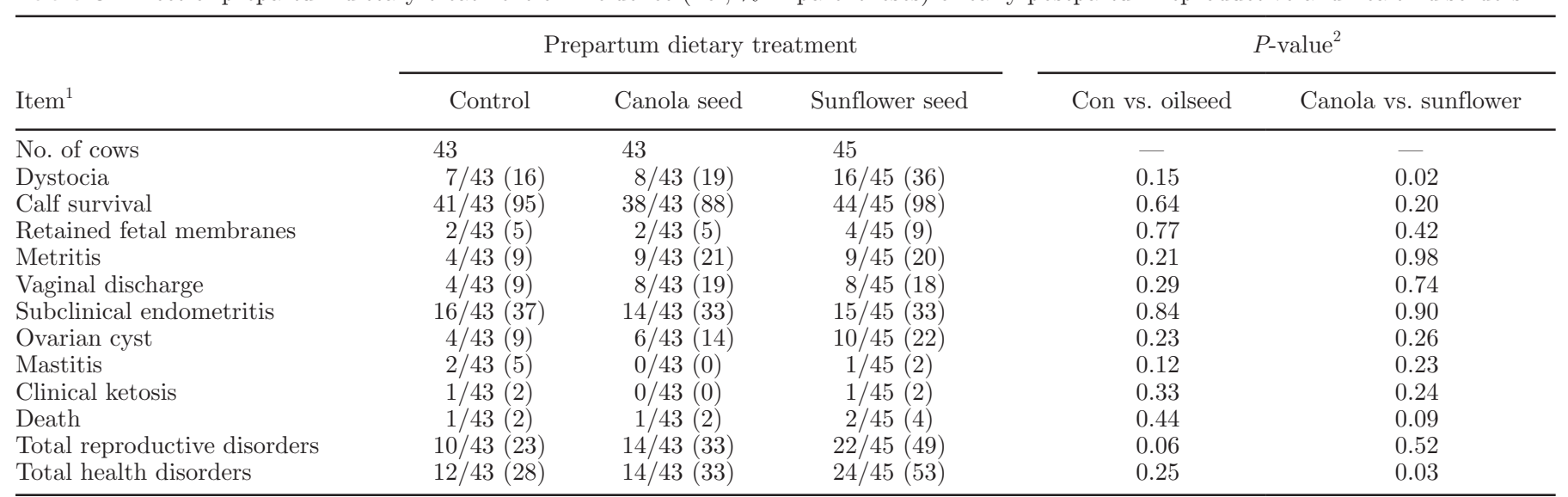

${ }^{1}$ Calf survival $=$ calf delivered alive; total reproductive disorders $=$ sum of retained fetal membranes, metritis, vaginal discharge and ovarian cyst incidence; total health disorders = sum of retained fetal membranes, metritis, vaginal discharge, ovarian cyst, clinical ketosis, mastitis, and dystocia.

${ }^{2}$ Con vs. oilseed $=$ no oilseed $($ control) vs. oilseed supplementation; canola vs. sunflower $=$ type of oilseed supplementation. 
Table 9. Effect of prepartum dietary treatments by polymorphonuclear cells (PMN) category interaction on intervals (mean \pm SEM) to dominant follicle formation, preovulatory-size follicle formation, and first ovulation

\begin{tabular}{|c|c|c|c|c|c|}
\hline \multirow[b]{2}{*}{ Item $^{1}$} & \multicolumn{3}{|c|}{ Prepartum dietary treatment } & \multicolumn{2}{|c|}{$P$-value ${ }^{2}$} \\
\hline & $\mathrm{CON}$ & Canola seed & Sunflower seed & $\begin{array}{l}\text { Con vs. } \\
\text { oilseeds }\end{array}$ & $\begin{array}{l}\text { Canola vs. } \\
\text { sunflower }\end{array}$ \\
\hline $\begin{array}{l}\text { No. of cows } \\
\leq 8 \% \text { PMN }\end{array}$ & 31 & 31 & 33 & - & - \\
\hline Interval to dominant follicle, $\mathrm{d}$ & $8.9 \pm 0.66$ & $8.9 \pm 0.52$ & $9.9 \pm 0.58$ & 0.54 & 0.21 \\
\hline Interval to preovulatory-size follicle, $\mathrm{d}$ & $13.6 \pm 1.10$ & $14.3 \pm 0.87$ & $15.6 \pm 0.97$ & 0.29 & 0.31 \\
\hline Proportion of pregnant cows by 150 DIM & $8 / 16(50.0)$ & $12 / 18(66.7)$ & $9 / 20(45.0)$ & 0.83 & 0.94 \\
\hline $\begin{array}{l}\text { Proportion of pregnant cows by } 250 \text { DIM } \\
>8 \% \text { PMN }\end{array}$ & $11 / 16(68.7)$ & $16 / 18(88.9)$ & $13 / 20(65.0)$ & 0.42 & 0.07 \\
\hline Interval to dominant follicle, $\mathrm{d}$ & $8.9 \pm 0.73$ & $11.0 \pm 1.04$ & $10.0 \pm 0.66$ & 0.10 & 0.43 \\
\hline Interval to preovulatory-size follicle, $\mathrm{d}$ & $14.1 \pm 1.23$ & $17.8 \pm 1.73$ & $15.1 \pm 1.10$ & 0.15 & 0.20 \\
\hline Interval to first ovulation, $\mathrm{d}$ & $20.5 \pm 2.44$ & $21.8 \pm 3.43$ & $20.1 \pm 2.18$ & 0.89 & 0.68 \\
\hline Pregnancy at first AI, $d$ & $2 / 15(14.3)$ & $2 / 13(16.7)$ & $3 / 13(23.0)$ & 0.60 & 0.96 \\
\hline
\end{tabular}

${ }^{1}$ Dominant follicle $=$ follicle of $\geq 10 \mathrm{~mm}$ diameter; preovulatory-size follicle $=$ follicle of $\geq 16 \mathrm{~mm}$ diameter.

${ }^{2}$ Con vs. oilseed $=$ no oilseed $($ control) vs. oilseed supplementation; canola vs. sunflower $=$ type of oilseed supplementation.

practices could explain the discrepancies among experiments. Regardless of dietary treatment, in the current study, the overall interval to ovulation was $21.4 \pm 1.5$ $\mathrm{d}$, which is similar to that reported by Colazo et al. (2009) for cows fed prepartum diets supplemented with flax $(21.0 \pm 3.1 \mathrm{~d})$ or linola $(23.7 \pm 3.2 \mathrm{~d})$. However, in the study by Colazo et al. (2009), the interval from calving to first ovulation in canola-fed cows was $34.7 \pm$ $3.1 \mathrm{~d}$, which is considerably longer than the $22.9 \pm 1.5$ d observed in our study. Notably, the study by Colazo et al. (2009) and the current study were performed in the same herd with no substantial differences in herd management practices in the years between the 2 study periods. One reason for discrepancies in the intervals to ovulation between the 2 experiments could be the greater incidence of ovarian follicular cyst in canola treatment in the previous study (Colazo et al., 2009) compared with our current study ( 25 vs. $14 \%$, respectively).

Sartori et al. (2013) reported that DMI (energy intake) could alter ovarian physiology and hormone concentrations. They found that cows with greater DMI had larger ovulatory follicles and CL volume than those with lower DMI (Sartori et al., 2013). In the current study, we found no association between DMI and interval from calving to first dominant follicle, but postpartum DMI was correlated with the interval to preovulatory-size follicle: the greater the postpartum DMI, the shorter the interval from calving to preovulatory-size follicle. However, we detected no association of pre- and postpartum DMI with the interval to first ovulation.
One of the factors affecting resumption of ovulation is postpartum health (Beam and Butler, 1997; Opsomer et al., 2000; Wathes et al., 2007a). The most common risk factor associated with dystocia in dairy cattle is oversized calves (Mee, 2012). There is an association between calf birth weight and dystocia, which is dependent on pelvic area, breed, parity, and dystocia case definition (Mee, 2012). For Holstein cows, the range is between 42 and $45 \mathrm{~kg}$ of birth weight, above which the dystocia rate increases significantly (Menissier and Foulley, 1979). Although mean calf birth weight for cows fed no oilseed was lower than the threshold reported by Menissier and Foulley (1979), mean calf birth weights in cows fed canola and sunflower were in the middle and the highest level of the range, respectively. Additionally, in the present study, there was an interaction between dietary treatment and calf sex, with oilseed-fed cows, particularly those fed sunflower seed, delivering heavier female calves than those fed the control diet. Male calves are approximately $9 \%$ heavier than female calves (Kertz et al., 1997). Johanson and Berger (2003) indicated that the majority of the increase in dystocia rate associated with male calves is attributable to their greater BW. Whereas male calves in the control and canola treatments were 8.17 and $6.76 \%$ heavier, respectively, than female calves, male calves in the sunflower treatment were marginally lighter $(-0.66 \%)$ than female calves in the same treatment group. Therefore, we could conclude that the increase of dystocia incidence in sunflower-fed cows resulted from both a greater male-to-female ratio and an increased female calf birth weight, which may have 
consequently increased the total health disorders during the postpartum period. Although the increased birth weight of calves was associated with prepartum DMI when all cows were considered regardless of dietary treatments, a similar association was found in the control and canola-fed cows when treatment groups were considered separately. However, prepartum DMI and calf birth weight were not associated in sunflower-fed cows. In view of the latter finding, it is rather intriguing how dietary inclusion of sunflower seed differentially affected birth weight in a sex-specific manner, favoring weight gain in female fetuses. As neither prepartum energy intake nor energy balance differed among the oilseed groups, we speculate that the high linoleic acid content in the sunflower seed may have played a role in the increased birth weight of female calves. In rodents, estrogen plays a key role in fatty acid unsaturation (Ostwald et al., 1966), allowing somatic tissues of female rats to accumulate greater quantities of unsaturated fatty acids than that of male rats (Pudelkewicz et al., 1968), without any differences in BW. It is not clear whether such reports exist for ruminants or whether preferential accumulation of unsaturated fatty acids in female fetuses, if provable, could increase BW. Nevertheless, future studies in cattle should investigate if our finding of a disproportionate increase in female calf birth weight in cows fed sunflower seed is repeatable.

Calf birth weight is affected by gestation length, which in turn is influenced by parity, fetal sex, maternal nutrition, sire (Mee, 2012), and heat stress (Tao and Dahl, 2013). It is noteworthy that short and long gestation lengths, which are associated with increased risk of dystocia, are defined as $<265 \mathrm{~d}$ or $>285 \mathrm{~d}$, respectively (Philipsson, 1976). Regardless of dietary treatment, the average gestation length in the present study was $275.3 \mathrm{~d}$, which is well within the normal gestation length reported by Norman et al. (2009). Moreover, gestation length was not affected by either parity or calf sex. A diet high in linoleic acid (e.g., a diet supplemented with sunflower) is generally thought to be associated with an increased risk of preterm delivery (Wathes et al., 2007b). In this regard, sheep fed a diet rich in linoleic acid during late gestation had greater circulating concentrations of 2-series prostaglandins, produced more prostaglandins in uterine and placental tissues, and appeared to be more susceptible to preterm parturition (Elmes et al., 2004; Cheng et al., 2005). Similar observations have been reported in women, where those who delivered prematurely had greater n-6 (i.e., linoleic acid) PUFA concentrations in erythrocytes (Reece et al., 1996, 1997). In dairy cows, feeding a diet supplemented with safflower oil (high in linoleic acid) for $30 \mathrm{~d}$ before expected date of calving did not affect gestation length compared with those fed palm oil (Silvestre et al., 2011a). However, our results contradict previous findings in cows, ewes, and women. Although the underlying mechanisms are not known, oilseed supplementation increased gestation length by 3 to $4 \mathrm{~d}$ in our study. As we had no control over sire selection, semen from 39 different sires were randomly used in current study, negating the possibility for any meaningful statistical evaluation of sire effect on gestation length. Fetal growth rate averages 0.3 to $0.4 \mathrm{~kg} / \mathrm{d}$ during the last month of gestation (Meijering, 1984). Thus, it could be expected that a 3- to 4-d-longer gestation length would result in an increase in calf birth weight of approximately 0.9 to $1.6 \mathrm{~kg}$, whereas feeding sunflower increased birth weight by $5 \mathrm{~kg}$ in female calves. Therefore, it could be speculated that calf birth weight was mainly affected by prepartum maternal nutrition (oilseed supplementation) rather than by gestation length. We infer that feeding oilseeds, particularly sunflower seed, during the prepartum period increased the incidence of dystocia, most likely through increased calf birth weight, and subsequently greater health disorders than in cows fed a diet with no oilseeds.

Juchem et al. (2010) reported that feeding calcium salts of linoleic and trans-octadecenoic acids from $25 \mathrm{~d}$ prepartum to $80 \mathrm{~d}$ postpartum enhanced fertility and reduced the incidence of puerperal metritis compared with those fed palm oil. Feeding a diet supplemented with safflower oil during the transition period induced a proinflammatory state during the first week postpartum, as evidenced by the increased neutrophil expression of adhesion molecules, production of cytokines, enhanced bactericidal activity, and increased circulating acute phase proteins compared with palm oil (Silvestre et al., 2011). However, in the present study, prepartum oilseed and type of oilseed supplementation did not affect the proportion of cows with subclinical endometritis. Our results are in agreement with the findings of Amaral (2008), wherein cows were fed a diet supplemented with calcium salts of safflower oil, a mix of palm and fish oil, or a control diet (no fat supplement) from $34 \mathrm{~d}$ prepartum until $49 \mathrm{~d}$ postcalving. The concentration of neutrophils in the uterine flushing and neutrophils as a proportion of total cells or as a proportion of white blood cells also did not differ among treatments at $37 \pm$ 3 d postpartum (Amaral, 2008). Current results on the association between PMN percentage and interval from calving to the establishment of dominant and preovulatory-size follicles partially support those reported by Dourey et al. (2011). They found that cows with $>8 \%$ PMN on d 25 had a longer interval from calving to first ovulation (45 vs. $32 \mathrm{~d}$ ).

Prepartum oilseed supplementation and type of supplemental oilseeds did not affect pregnancy at first AI or the proportion of pregnant cows by 150 DIM in 
the current study, but oilseed supplementation tended to improve the proportion of pregnant cows by 250 DIM. Similarly, feeding of oilseed (Colazo et al., 2009) or n-3 fatty acid (Optomega, Optivite Co., Worksop, UK; Badiei et al., 2014) prepartum did not influence postpartum reproductive performance. However, in studies where feeding dietary fatty acids prepartum was continued to either 80 (trans-octadecenoic fatty acids; Juchem et al., 2010) or 160 d postpartum (fish oil; Silvestre et al., 2011a), pregnancy rate at first or second AI, respectively, was improved. Thus, benefits to altering the fatty acid profile in the diet of dairy cows may depend on both the length of the dietary period during which they consume the respective fatty acids and the type of fat supplemented. The moderate increase in the proportion of pregnant cows by 250 DIM observed in the present study might not be related to prepartum oilseed supplementation.

\section{Feed Intake, Plasma Metabolites, Milk Yield, and Composition}

In the current study, oilseed supplementation had different effects on the DMI of primiparous and multiparous cows. In primiparous cows, prepartum oilseed supplementation did not affect prepartum DMI compared with control, but increased postpartum DMI. In multiparous cows, prepartum oilseed supplementation decreased both prepartum and postpartum DMI. Primiparous and multiparous cows used in the current study had moderate BCS $(3.36 \pm 0.14$ and $3.29 \pm 0.21$, respectively; mean $\pm \mathrm{SD}$ ), and it is noteworthy that high fat diets decreased the DMI of multiparous cows that were not overconditioned. Our DMI results are in contrast to that of Garcia et al. (2014), who fed cows 3 diets during the last 8 wk of gestation: no fat supplementation (control), enriched in saturated fatty acids (mainly stearic acid, 1.7\% of DM; Energy Booster 100, Milk Specialties, Dundee, IL), or enriched in essential fatty acids (1.7\% of DM; Megalac R, Church and Dwight, Princeton, NJ). They found that neither prepartum fat supplementation nor the type of fatty acid fed affected mean DMI during prepartum period, although cows fed essential fatty acids consumed 0.9 $\mathrm{kg} / \mathrm{d}$ less DM compared with those fed diets enriched in saturated fatty acids. Colazo et al. (2009) also found feeding different types of oilseeds did not affect pre- and postpartum DMI. However, in both studies (Colazo et al., 2009; Garcia et al., 2014), the interaction of treatment by parity for DMI was not considered. Therefore, we conclude that DMI responses to prepartum fat supplementation were affected by parity.

Firkins and Eastridge (1994) evaluated treatment means from 11 experiments and reported that DMI decreased as the degree of unsaturation of long-chain fatty acid increased. In the present study, the type of supplemental oilseed (canola vs. sunflower) did not affect prepartum DMI, but cows fed canola prepartum had lower DMI during the postpartum period than those fed sunflower, regardless of parity. However, the type of supplemental oilseed (canola vs. sunflower) did not affect fatty acids concentration during the pre- and postpartum periods. Canola seed contained more oleic and $\alpha$-linolenic acids and less linoleic acid than sunflower seed, which were reflected in plasma fatty acid profile. In a previous in vitro hepatocyte metabolism study, Mashek et al. (2002) found that palmitic acid metabolism was greater when incubated with oleic or $\alpha$-linolenic acid compared with linoleic acid, increasing oxidative metabolism and triacylglycerol synthesis in hepatocytes. Therefore, in the current study, feeding canola seed prepartum might have increased triacylglycerol accumulation in the liver, which is known to decrease postpartum DMI (Grummer, 1993). Moreover, $\alpha$-linolenic acid can activate peroxisome proliferatoractivated receptors and induce hepatic fatty acid oxidation (Jump et al., 2005). Feeding canola seed, which contained more $\alpha$-linolenic acid than sunflower seed, prepartum might have enhanced fatty acid oxidation to a greater extent in the liver after calving, and greater hepatic oxidation may lead to lower postpartum DMI (Allen et al., 2009). However, a specific mechanism cannot be identified from the data obtained from the current study, warranting further investigation.

Grum et al. (1996) showed that prepartum fat supplementation increased fatty acids without affecting BHB and glucose. Similarly, in our study, prepartum dietary treatments did not affect plasma BHB or glucose concentration during the pre- and postpartum periods. The data of Grummer and Carroll (1991) indicated that the effects of fat supplementation on plasma BHB were inconsistent. The elevation in plasma BHB concentrations in response to fat supplementation seems to depend on the metabolic status of the cow. During the transition period, when concentrations of plasma fatty acids increase, there is a greater probability of a coincidental increase in plasma BHB concentrations than later in lactation (Grummer and Carroll, 1991).

Previous studies have shown inconsistent results of milk production and composition in response to fat supplementation. Douglas et al. (2004) and Ballou et al. (2009) indicated that feeding multiparous cows a diet supplemented with fat during the prepartum period did not affect milk yield and composition. However, prepartum oilseed supplementation reduced milk yield in multiparous cows during early postpartum and milk protein yield in $\mathrm{wk}+2$ in the present study. It also increased lactose (\%) and tended to decrease milk 
fat yield in wk +5 . Duske et al. (2009) reported that feeding cows diets supplemented with fat prepartum decreased milk yield and lactose (\%), but increased fat (\%) during first $4 \mathrm{wk}$ postpartum. A recent metaanalysis and meta-regression by Rabiee et al. (2012) indicated that feeding oilseeds has no effect on milk yield but did reduce milk fat (\%) and protein (\%). Additionally, Rabiee et al. (2012) indicated that milk yield is positively correlated with DMI. We infer that feeding high-fat diets during the prepartum period reduced DMI, resulting in reduced milk yield in multiparous cows.

\section{CONCLUSIONS}

Oilseed supplementation during the prepartum period reduced DMI and milk yield in multiparous cows, and increased female calf birth weight. Dystocia and total health disorders were increased in cows fed supplemental sunflower seed prepartum than in those fed canola. However, neither prepartum oilseed supplementation nor the type of oilseed affected pregnancy at first service or the proportion of pregnant cows by 150 DIM. Although our earlier finding of a longer interval from calving to first ovulation in cows fed canola in the prepartum period was a basis for the present study, we were unable to find any evidence of prepartum diets influencing postpartum ovarian function through alterations in the interval from calving to first ovulation.

\section{ACKNOWLEDGMENTS}

This study was supported by Alberta Livestock and Meat Agency (Edmonton, AB, Canada), Alberta Innovates - Bio Solutions (Edmonton, AB, Canada), Alberta Milk (Edmonton, AB, Canada), and Livestock Research Branch, Alberta Agriculture and Forestry (Edmonton, AB, Canada). The authors thank Mohanathas Gobikrushanth, Ana Ruiz-Sanchez, and Amir Behrouzi (Department of Agricultural, Food and Nutritional Science, University of Alberta, Edmonton, AB, Canada) for their technical assistance.

\section{REFERENCES}

Allen, M. S., B. J. Bradford, and M. Oba. 2009. The hepatic oxidation theory of the control of feed intake and its application to ruminants. J. Anim. Sci. 87:3317-3334.

Amaral, B. C. D. 2008. Effect of supplemental fat source on production, immunity, hepatic gene expression, and metabolism of periparturient dairy cows. PhD Diss. University of Florida, Gainesville.

Ambrose, D. J., and M. G. Colazo. 2007. Reproductive status of dairy herds in Alberta: A closer look. Proc. 25th Western Can. Dairy Sem. Adv. Dairy Technol. 19:227-244.

Ambrose, D. J., J. P. Kastelic, R. Corbett, P. A. Pitney, H. V. Petit, J. A. Small, and P. Zalkovic. 2006. Lower pregnancy losses in lac- tating dairy cows fed a diet enriched in $\alpha$-linolenic acid. J. Dairy Sci. 89:3066-3074.

AOAC International. 2002. Official Methods of Analysis. 17th ed. AOAC International, Gaithersburg, MD.

Badiei, A., A. Aliverdilou, H. Amanlou, M. Beheshti, E. Dirandeh, R. Masoumi, F. Moosakhani, and H. V. Petit. 2014. Postpartum responses of dairy cows supplemented with n-3 fatty acids for different durations during the peripartal period. J. Dairy Sci 97:6391-6399.

Ballou, M. A., R. C. Gomes, S. O. Juchem, and E. J. DePeters. 2009. Effects of dietary supplemental fish oil during the peripartum period on blood metabolites and hepatic fatty acid compositions and total triacylglycerol concentrations of multiparous Holstein cows. J. Dairy Sci. 92:657-669.

Beam, S. W., and W. R. Butler. 1997. Energy balance and ovarian follicle development prior to the first ovulation postpartum in dairy cows receiving three levels of dietary fat. Biol. Reprod. 56:133-142.

Bell, A. W. 1981. Lipid metabolism in liver and selected tissues and in the whole body of ruminant animals. Page 363-399 in Lipid Metabolism in Ruminant Animals. 1st ed. W. W. Christie, ed. Pergamon Press, Oxford, UK.

Bell, A. W. 1995. Regulation of organic nutrient metabolism during the transition from late pregnancy to early lactation. J. Anim. Sci. $73: 2804-2819$.

Caldari-Torres, C., A. L. Lock, C. R. Staples, and L. Badinga. 2011 Performance, metabolic, and endocrine responses of periparturient Holstein cows fed 3 sources of fat. J. Dairy Sci. 94:1500-1510.

Cheng, Z., M. Elmes, S. E. Kirkup, E. C. Chin, D. R. E. Abayasekara, and D. C. Wathes. 2005. The effect of a diet supplemented with n-6 polyunsaturated fatty acid (PUFA) linoleic acid on prostaglandin production in early and late pregnant ewes. J. Endocrinol. 184:165-178.

Colazo, M. G., A. Hayirli, L. Doepel, and D. J. Ambrose. 2009. Reproductive performance of dairy cows is influenced by prepartum feed restriction and dietary fatty acid source. J. Dairy Sci 92:2562-2571

Cruz-Hernandez, C., J. K. G. Kramer, J. J. Kennelly, D. R. Glimm, B. M. Sorensen, E. K. Okine, L. A. Goonewardene, and R. J. Weselake. 2007. Evaluating the conjugated linoleic acid and trans 18:1 isomers in milk fat of dairy cows fed increasing amounts of sunflower oil and a constant level of fish oil. J. Dairy Sci. 90:3786-3801.

Douglas, G. N., T. R. Overton, H. G. Bateman II, and J. K. Drackley. 2004. Peripartal metabolism and production of Holstein cows fed diets supplemented with fat during the dry period. J. Dairy Sci. $87: 4210-4220$.

Dourey, A., M. G. Colazo, P. P. Barajas, and D. J. Ambrose. 2011. Relationships between endometrial cytology and interval to first ovulation, and pregnancy in postpartum dairy cows in a single herd. Res. Vet. Sci. 91:e149-e153.

Drackley, J. K. 1999. Biology of dairy cows during the transition period: The final frontier? J. Dairy Sci. 82:2259-2273.

Duske, K., H. M. Hammon, A. K. Langhof, O. Bellmann, B. Losand, K. Nürnberg, G. Nürnberg, H. Sauerwein, H. M. Seyfert, and C. C. Metges. 2009. Metabolism and lactation performance in dairy cows fed a diet containing rumen-protected fat during the last twelve weeks of gestation. J. Dairy Sci. 92:1670-1684.

Edmonson, A. J., I. J. Lean, L. D. Weaver, T. Farver, and G. Webster. 1989. A body condition scoring chart of Holstein dairy cows. J. Dairy Sci. 72:68-78.

Elmes, M., P. Tew, Z. Cheng, S. E. Kirkup, D. R. E. Abayasekara, P. C. Calder, M. A. Hanson, D. C. Wathes, and G. C. Burdge. 2004. The effect of dietary supplementation with linoleic acid to late gestation ewes on the fatty acid composition of maternal and fetal plasma and tissues and the synthetic capacity of the placenta for 2-series prostaglandins. Biochim. Biophys. Acta 1686:139-147.

Firkins, J. L., and M. L. Eastridge. 1994. Assessment of the effects of iodine value on fatty acid digestibility, feed intake, and milk production. J. Dairy Sci. 77:2357-2366.

Folch, J., M. Lees, and G. H. Sloane Stanley. 1957. A simple method for the isolation and purification of total lipids from animal tissues. J. Biol. Chem. 226:497-509. 
Garcia, M., L. F. Greco, M. G. Favoreto, R. S. Marsola, L. T. Martins, R. S. Bisinotto, J. H. Shin, A. L. Lock, E. Block, W. W. Thatcher, J. E. Santos, and C. R. Staples. 2014. Effect of supplementing fat to pregnant nonlactating cows on colostral fatty acid profile and passive immunity of the newborn calf. J. Dairy Sci. 97:392-405.

Garverick, H. A. 1997. Ovarian follicular cysts in dairy cows. J. Dairy Sci. 80:995-1004.

Grum, D. E., J. K. Drackley, R. S. Younker, D. W. LaCount, and J. J. Veenhuizen. 1996. Nutrition during the dry period and hepatic lipid metabolism of periparturient dairy cows. J. Dairy Sci. 79:1850-1864.

Grummer, R. R. 1993. Etiology of lipid-related metabolic disorders in periparturient dairy cows. J. Dairy Sci. 76:3882-3896.

Grummer, R. R., and D. J. Carroll. 1991. Effects of dietary fat on metabolic disorders and reproductive performance of dairy cattle. J. Anim. Sci. 69:3838-3852.

Gümen, A., R. R. Rastani, R. R. Grummer, and M. C. Wiltbank. 2005. Reduced dry periods and varying prepartum diets alter postpartum ovulation and reproductive measures. J. Dairy Sci. $88: 2401-2411$.

Herdt, T. H. 1988. Fatty liver in dairy cows. Vet. Clin. North Am. Food Anim. Pract. 4:269-287.

Johanson, J. M., and P. J. Berger. 2003. Birth weight as a predictor of calving ease and perinatal mortality in Holstein cattle. J. Dairy Sci. 86:3745-3755

Juchem, S. O., R. L. A. Cerri, M. Villaseno r, and K. N. Galva.Bruno, R. G. S., H. M. Rutigliano, E. J. DePeters, F. T. Silvestre, W. W. Thatcher, and J. E. P. Santos. 2010. Supplementation with calcium salts of linoleic and trans-octadecenoic acids improves fertility of lactating dairy cows. Reprod. Domest. Anim. 45:55-62.

Jump, D. B., D. Botolin, Y. Wang, J. Xu, B. Christian, and O. Demeure. 2005. Fatty acid regulation of hepatic gene transcription. J. Nutr. 135:2503-2506.

Kertz, A. F., L. F. Reutzel, B. A. Barton, and R. L. Ely. 1997. Body weight, body condition score, and wither height of prepartum Holstein cows and birth weight and sex of calves by parity: A database and summary. J. Dairy Sci. 80:525-529.

Mashek, D. G., S. J. Bertics, and R. R. Grummer. 2002. Metabolic fate on long-chain unsaturated fatty acids and their effects on palmitic acid metabolism and gluconeogenesis in bovine hepatocytes. J. Dairy Sci. 85:2283-2289.

Mee, J. 2012. Prevalence and risk factors for dystocia in dairy cattleWith emphasis on confinement systems. Proc. 30th Western Can. Dairy Sem. Adv. Dairy Technol. 24:113-125.

Meijering, A. 1984. Dystocia and stillbirth in cattle - A review of causes, relations and implications. Livest. Prod. Sci. 11:143-177.

Menissier, F., and J. L. Foulley. 1979. Present situation of calving problems in the EEC. Incidence of calving difficulties and early calf mortality in beef breeds. In Calving Problems and Early Viability of the Calf. EEC Seminar, May 1977, Frising, Germany. Curr. Top. Vet. Med. Ans. 4:30-85.

Moreira, F., C. Orlandi, C. A. Risco, R. Mattos, F. Lopes, and W. W. Thatcher. 2001. Effects of presynchronization and bovine somatotropin on pregnancy rates to a timed artificial insemination protocol in lactating dairy cows. J. Dairy Sci. 84:1646-1659.

Norman, H. D., J. R. Wright, M. T. Kuhn, S. M. Hubbard, J. B. Cole, and P. M. VanRaden. 2009. Genetic and environmental factors that affect gestation length in dairy cattle. J. Dairy Sci. 92:22592269 .

Olfert, D. E., B. M. Cross, and A. A. McWilliam, eds. 1993. Pages 31-34 in Guide to the Care and Use of Experimental Animals. 2nd ed. Vol. 1. Canadian Council on Animal Care, Ottawa, Canada.

Opsomer, G., Y. T. Grohn, J. Hertl, M. Coryn, H. Deluyker, and A. deKruif. 2000. Risk factors for postpartum ovarian dysfunction in high producing dairy cows in Belgium: A field study. Theriogenology $53: 841-857$.

Ostwald, R., P. Bouchard, A. Shannon, P. Miljanick, and R. L. Lyman. 1966. Effect of estradiol and testosterone on the metabolism of linoleate in essential fatty acid-deficient rats. J. Nutr. 88:303-314.

Philipsson, J. 1976. Studies on calving difficulty, stillbirth and associated factors in Swedish cattle breeds: III. Genetic parameters. Acta Agric. Scand. 26:211-220.

Pudelkewicz, C., J. Seufert, and R. T. Holman. 1968. Requirements of the female rat for linoleic and linolenic acids. J. Nutr. 94:138-146.

Rabiee, A. R., K. Breinhild, W. Scott, H. M. Golder, E. Block, and I. J. Lean. 2012. Effect of fat additions to diets of dairy cattle on milk production and components: A meta-analysis and metaregression. J. Dairy Sci. 95:3225-3247.

Reece, M. S., J. A. McGregor, K. G. Allen, and M. A. Harris. 1997. Maternal and perinatal long-chain fatty acids: possible roles in preterm birth. Am. J. Obstet. Gynecol. 176:907-914.

Reece, M. S., J. A. McGregor, K. G. Allen, M. M. Mathias, and M. A. Harris. 1996. Prostaglandins in selected reproductive tissues in preterm and term gestations. Prostaglandins Leukot. Essent. Fatty Acids 55:303-307.

Roberts, S. J. 1986.Veterinary Obstetrics and Genital Diseases. 3rd ed. David and Charles Inc., North Pomfret, VT.

Santos, J. E. P., T. Bilby, W. W. Thatcher, C. R. Staples, and F. T. Silvestre. 2008. Long chain fatty acids of diet as factors influencing reproduction in cattle. Reprod. Domest. Anim. 43(Suppl. 2):23-30.

Sartori, R., M. M. Guardieiro, R. S. Surjus, L. F. Melo, A. B. Prata, M. Ishiguro, M. R. Bastos, and A. B. Nascimento. 2013. Metabolic hormones and reproductive function in cattle. Anim. Reprod. 10:199-205.

Schalm, O. W., and D. O. Noorlander. 1957. Experiments and observations leading to development of the California Mastitis Test. J. Am. Vet. Med. Assoc. 130:199-204.

Sewalem, A., F. Miglior, G. Kistemaker, P. Sullivan, and B. Van Doormaal. 2008. Relationship between reproduction traits and functional longevity in Canadian dairy cattle. J. Dairy Sci. 91:1660-1668.

Sheldon, I. M., G. S. Lewis, S. LeBlanc, and R. O. Gilbert. 2006. Defining postpartum uterine disease in cattle. Theriogenology 65:1516-1530.

Silvestre, F. T., T. S. Carvalho, P. C. Crawford, J. E. Santos, C. R. Staples, T. C. Jenkins, and W. W. Thatcher. 2011. Effects of differential supplementation of fatty acids during the peripartum and breeding periods of Holstein cows: II. Neutrophil fatty acids and function, and acute phase proteins. J. Dairy Sci. 94:2285-2301.

Silvestre, F. T. T. S. Carvalho, N. Francisco, J. E. Santos, C. R. Staples, T. C. Jenkins, and W. W. Thatcher. 2011a. Effects of differential supplementation of fatty acids during the peripartum and breeding periods of Holstein cows: I. Uterine and metabolic responses, reproduction, and lactation. J. Dairy Sci. 94:189-204.

Sun, Y., and M. Oba. 2014. Effects of feeding a high-fiber byproduct feedstuff as a substitute for barley grain on rumen fermentation and productivity of dairy cows in early lactation. J. Dairy Sci. 97:1594-1602.

Tao, S., and G. E. Dahl. 2013. Invited review: Heat stress effects during late gestation on dry cows and their calves. J. Dairy Sci. 96:4079-4093.

Wathes, D. C., N. Bourne, Z. Cheng, G. E. Mann, V. J. Taylor, and M. P. Coffey. 2007a. Multiple correlation analyses of metabolic and endocrine profiles with fertility in primiparous and multiparous cows. J. Dairy Sci. 90:1310-1325.

Wathes, D. C., D. Robert, E. Abayasekara, and R. J. Aitken. 2007b. Polyunsaturated fatty acids in male and female reproduction. Biol. Reprod. 77:190-201. 